\title{
Internet-based French as a Foreign Language Vocabulary Learning: Academic Success and Opinions on FFL Learners
}

\author{
Senem Seda Şahenk Erkan \\ Foreign Languages Department, Marmara University, Istanbul, Turkey
}

Copyright(C2017 by authors, all rights reserved. Authors agree that this article remains permanently open access under the terms of the Creative Commons Attribution License 4.0 International License

\begin{abstract}
In the $21^{\text {st }}$ century, globalization and technological developments in different domains of life have accentuated the importance of multilingualism and multiculturalism in studying English and French as foreign languages in different countries of the world, including Turkey. This research is aimed at determining the effects of learning vocabulary in French as a foreign language (FFL) through internet-based study. This study used a mixed-method (quantitative and qualitative) approach. In the 2016-2017 academic year, 85 Turkish university students (in 20-23 ages) participated in this study. A vocabulary test and a semi-prepared interview form are prepared to collect the data for this research. In this study, Turkish university students studying vocabulary using internet-based research justify their ability to improve French language knowledge easily and efficiently.
\end{abstract}

Keywords Internet-based Learning, Studying Vocabulary, FFL University Students

\section{Introduction}

Many aspects of the modern world are influenced by the developments in technology, politics, economics, education, etc...This period is deemed as the century of information, globalization and communication. In such a setting, teaching and learning foreign languages can permit every citizen to form a solid future for him- or herself and also for his or her family and his or her country. The next generations can easily acquire and transfer their knowledge from their native tongue to a foreign language(s). The language contact-contrast dynamics can therefore be viewed as a solid building block that allows a learner to structure the acquisition and transmission of knowledge. For these reasons, multilingualism can be used as a tool in the construction of wide-broaded knowledge. Multilingualism and multiculturalism can be developed using a didactic approach restructured through an essentially sociolinguistic conceptualization, reformed by the learner's role of speaker-as-actor [1].

Today, due to the influence of the world-wide phenomenon, English is the first foreign language that everybody seeks to learn. After English, French is the second foreign language to learn, as approximatively 200.000.000 people in 5 continents speak French. Teaching English and also French allows to everybody to find new opportunities in their professional lives. Multilinguism offers individuals new opportunities in national and also international companies [2]. That's why citizens of Turkey, as in other countries in the world, try to learn French as a foreign language (FFL) after English.

There are 35 official and 185 recorded languages within the Council of Europe's 43 member states (Daoust, 1997). Protecting these linguistic and cultural differences while assuring the communication, interaction, and mobility within a forming European Union and across all of Europe, lead to the elaboration of the CEFR (Heyworth, 2004). The aims of Common European Framework are cited below [3]:

(i) "To promote and facilitate co-operation among educational institutions in different countries;

(ii) To provide a sound basis for the mutual recognition of language qualifications;

(iii) To assist learners, teachers, course designers, examining bodies, and educational administrators to situate and co-ordinate their efforts".

The Common European Framework of Reference (CEFR) was published by the Council of Europe in 2001. According to [4], "the CEFR is a descriptive scheme that can be formed to build L2 learners' needs, compose L2 learning objectives, guide the elaboration of L2 learning materials and activities, and assure orientation for the assessment of L2 learning data". The CEFR is structured by six levels of language proficiency (A1 (Breakthrough), A2 (Waystage), B1 (Threshold), B2 (Vantage), C1 (Effective Operational 
Proficiency), and C2 (Mastery)), referred to as Common Reference Levels (CRLs), which are "appropriate to the organization of language learning and the public recognition of achievement" (Council of Europe, 2001: 22-23, Introductory guide to the Common European Framework of Reference (CEFR) for English language teachers). The CEFR is structured with five foreign language skills: reading, writing, listening, spoken interaction, and spoken production [2].

This research is formed at the A1 (Breakthrough) language level. This is the first language level in 6 language levels of CEFR in which [3] "the learner can understand and use familiar everyday expressions and very basic phrases aimed at the satisfaction of needs of a concrete type. He/she can introduce him/herself and others and can ask and answer questions about personal details such as where he/she lives, people he/she knows and thing he/she has. $H e / s h e$ can interact in a simple way provided the other person talks slowly and clearly and is prepared to help."

Vocabulary knowledge is very important for language learners. Teaching vocabulary learning strategies can be very productive when teaching vocabularies. There are five steps in most of the vocabulary learning strategies [5]:

(i) "Facing the word,

(ii) Getting an image of the word in mind,

(iii) Learning the meaning,

(iv) Making a strong connection between form and meaning and

(v) Using the word."

Under this concept, many researchers have studied diverse aspects of vocabulary learning methodologies and the use of CEFR in foreign language classrooms ([6]; [7]; [8]; [9]; [10]; [11]; [12]; [13]; [14]; [15]; [16]; [17]; [18]; [19]; [20]; [21]; [22]; [23]; [24]; [25]; [26]; [27]; [28]; [29]; [30]; [31]; [32]; [33]; [34]; [35]; [36]; [37]; [38]; [39]; [40]; [41]; [42]; [43]; [44]; [45]; [46]; [47]; [48]; [49]; [50]; [51]; [52]; [53]; [54]; [55]; [56]).

The scheme below represents the users/learners' competences during the teaching of foreign language(s):

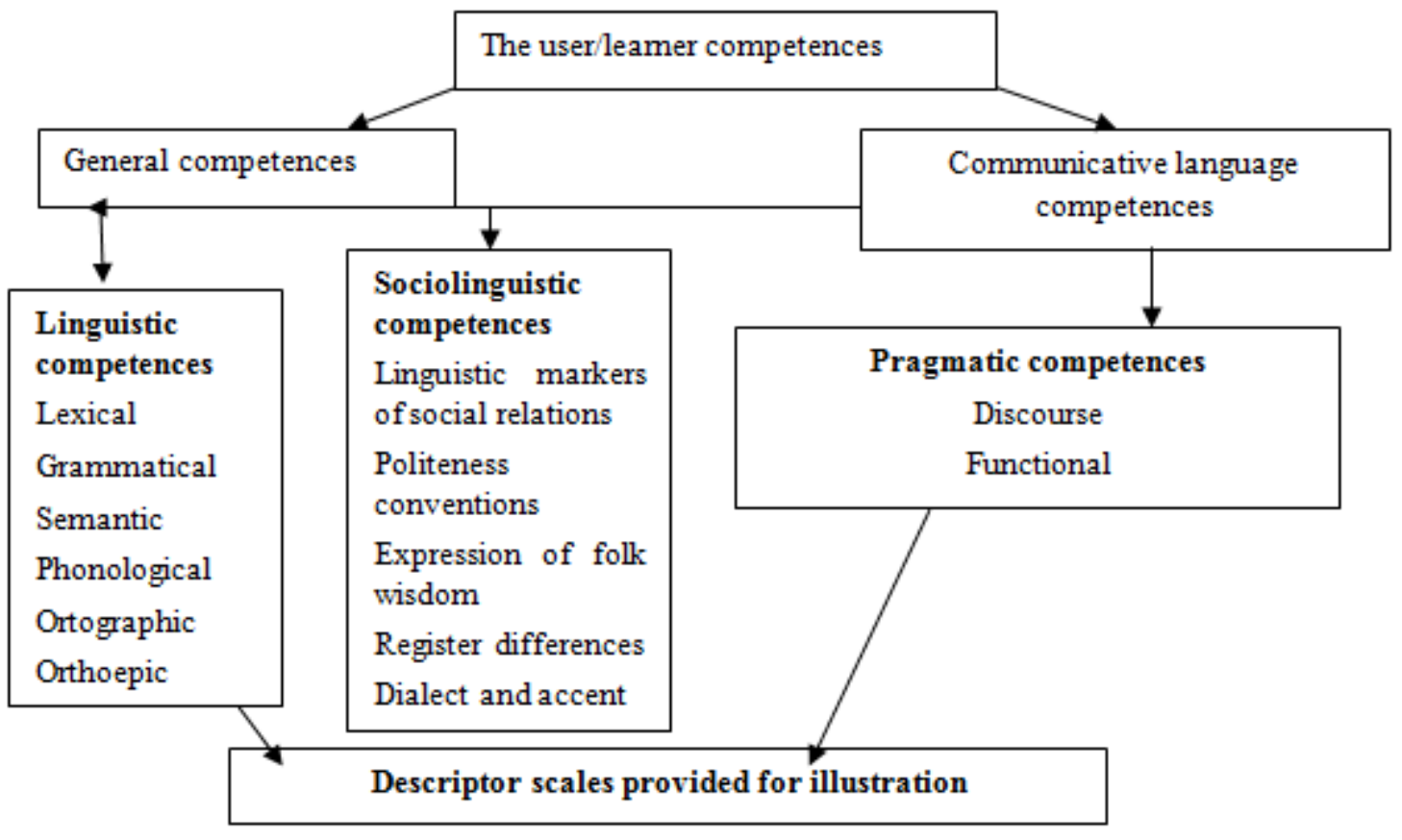

Figure 1. Language use and user/learner competence 


\section{References: [2].}

As seen in Figure 1, linguistic competences which include lexical, grammatical, semantic, and phonological competences (awareness) are essential aspects among the user/learner competences. Thus, as demonstrated in this article, during the teaching of foreign language(s), linguistic competences are very valuable for user/learner competences. This article proposes to benefit the linguistic competences containing lexical and grammatical competences (awareness) during the teaching of foreign languages. Also, it describes how one can profit from the linguistic competences during these activities in teaching foreign languages.

This article aims to analyze the learner linguistic competences during the teaching action of learning French as a foreign language (FFL).

\subsection{Studying Vocabulary While Teaching Foreign Languages}

"Knowing a word" actually "involves a lot more than might be imagined at first, as it contains understanding its meaning (for example its denotation, but also any figurative meaning it may have), knowing how to spell and pronounce it, what part of speech it is, which words it collocates with, how formal or informal it is, which context to use it in, what connotations it has, if prefixes and/or suffixes can be added to it to form new words, if it can be used in compounds, and even knowing its synonyms, antonyms, and sometimes origin" [57]. According to this perspective, the study of vocabulary acquisition is listed below [58]:

(i) "Order of acquisition of different types of knowledge (morphological, syntactic, collocational, semantic, etc.) for each lexical item;

(ii) Order of acquisition of word classes (noun, verb, adverb, adjective, etc.);

(iii) Order of acquisition of particular lexical items; and

(iv) Developmental stages of lexical processing."

According to [59], vocabulary learning strategies include knowledge about the mechanisms (processes, strategies) used in order to learn vocabulary as well as the steps or actions taken by students:

(i) To find out the meaning of unknown words;

(ii) To retain them in long-term memory;

(iii) To recall them at will; and

(iv) To use them in oral or written mode.

As explained by [60], vocabulary knowledge is developed in three major stages:

(i) The first stage involves associative learning, in which a student learns the definition of the word in only one particular context, such as through dictionary use.

(ii) The second is the comprehensive level at which a student understands the word and that word can be expanded upon because the student tries to study synonyms, antonyms, classification, analogies, and connotative dictionary meanings.

(iii) The third stage is the generative level at which learners can use any variation of the word significance independently in their speaking and writing; therefore, they can understand the word used in any context.

In Turkey, while learning foreign languages, for example during the action of studying French as a foreign language (FFL), grammar and vocabulary are essential parts of teaching FFL. Vocabulary has been a main component of foreign languages in FFL classrooms since 1980. Audio-lingual, direct, natural, suggestopedia, and grammar-translation methods are also applied in foreign language instruction to help learners develop a solid knowledge of vocabulary [61].

\section{Method}

This study collected the data using a mixed-method approach (quantitative (semi-prepared interview form) and qualitative researching methods (vocabulary test)). The design in question is analyzed through the collection and investigation of quantitative data in a first phase of research and is structured by the collection and observation of the consequences of qualitative data in the second phase, which is constructed on the analysis of the initial quantitative results [62].

\subsection{Sample}

The sample of this research is composed of 100 Turkish university students (63 girls and 37 boys in 20-23 ages) at Marmara University in Istanbul, Turkey, during the 2016-2017 academic year. The students were in $3^{\text {rd }}$ grade in the English teaching department. They studied French as a second foreign language for two hours per week and obtained a nearly A2 language level in French. This study constitutes of Internet-based vocabulary learning. The FFL learners tried to study vocabulary related to the family through Internet-based vocabulary study. This research is built by the application of the Internet site www.lexique.fle.fr for the FFL classroom [63].

\subsection{Vocabulary Test}

The vocabulary test was prepared with 3 questions worth 100 points. The first question prompted students to list the members of the family, worth 10 points. The second question required them to form sentences using 5 family words, worth 30 points. Finally, the third question prompted them to present their family using a minimum of 100 words and 10 sentences, worth 60 points.

\subsection{Application}

There are several Internet sites devoted to studying French vocabulary in the FFL classroom. For example, when the 
teacher or the learner clicks on https://www.lexiquefle.free.fr, he/she can click buttons to discover French vocabulary in different subjects, such as the body, the family, numbers, animals, the train station, in the city, and my home.
This research is based on the usage of the family option on this Internet site. As seen below, when the teacher or the learner clicks the family button, he/she can register this vocabulary program on his/her computer.

Table 1. Internet site regarding vocabulary related to the family

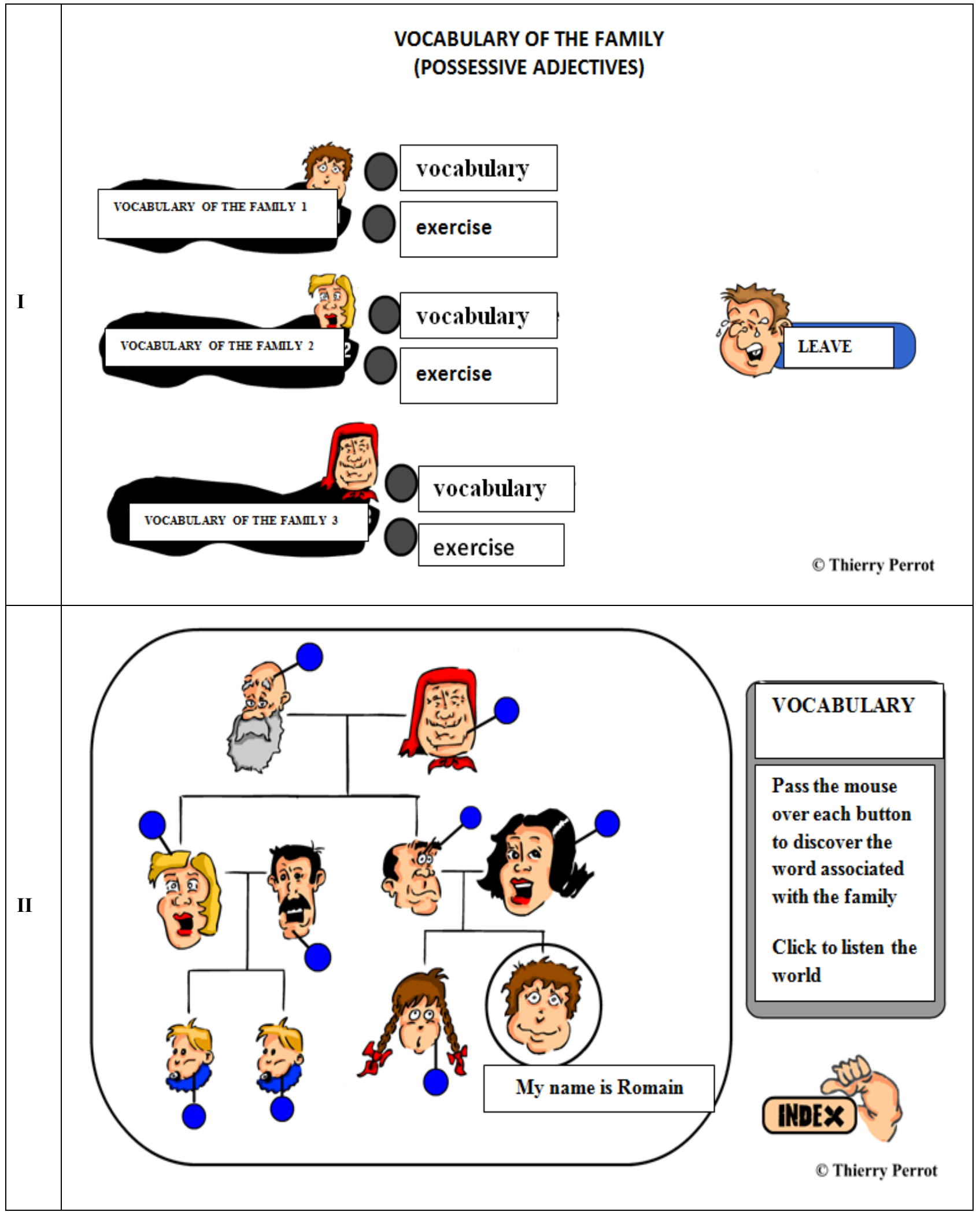




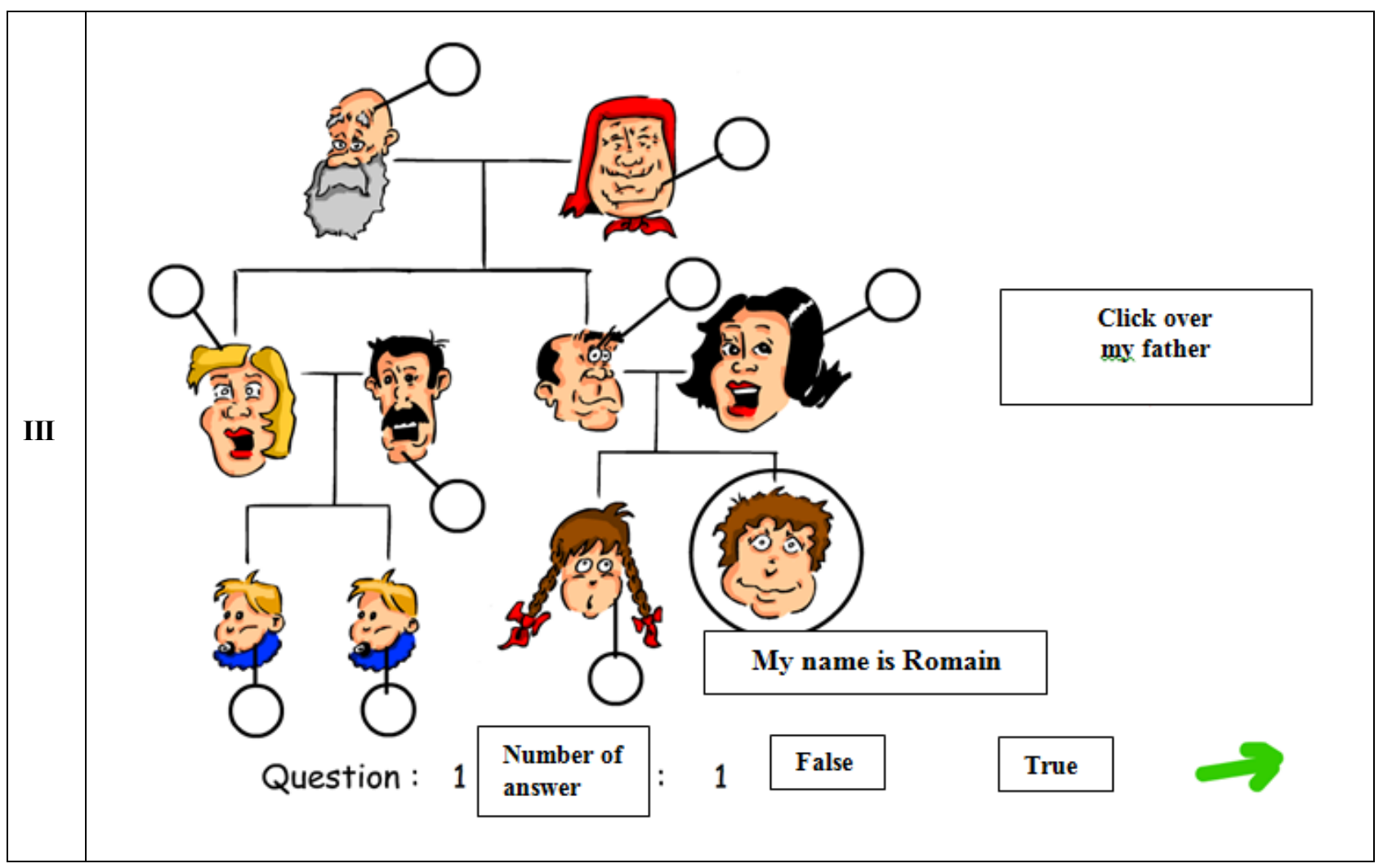

Reference: [63]

As seen in Table 1 below, this method of vocabulary learning is separated into three sections [60]:

(i) In the first part, students can learn 3 different vocabulary words with three various pictures;

(ii) In the second section, students can click on the image of each person of the family to learn the words for the members of family in French; and

(iii) In the third part, students can reply to each question about the members of the family. Finally, they discover if their answers are correct or not.

\subsection{Semi-prepared Interview Form}

A semi-prepared interview form is composed of 3 questions. 10 learners participated in the interview. The first question prompted them to report on their new knowledge of French vocabulary. The second question sought to gather the positive effects of this research. The third question sought to gather the negative consequences of this application in FFL classes.

\section{Findings}

The findings of vocabulary test and semi-prepared interview form are demonstrated step by step in this section.

\subsection{Results of Vocabulary Test}

The results of the vocabulary test are demonstrated in Table 2.

Table 2. Results of vocabulary test

\begin{tabular}{|c|c|c|c|}
\hline Vocabulary test & Scores & $\mathbf{N}$ & $\%$ \\
\hline \multirow{2}{*}{$\mathbf{1}^{\text {st }}$ question } & $\mathbf{0 - 5}$ pts. & 0 & 0 \\
& $\mathbf{6 - 1 0}$ pts. & 100 & 100 \\
\hline \multirow{2}{*}{$2^{\text {nd }}$ question } & $\mathbf{0 - 1 5}$ pts. & 0 & 0 \\
& $\mathbf{1 6 - 3 0}$ pts. & 100 & 100 \\
\hline \multirow{2}{*}{$\mathbf{3}^{\text {rd }}$ question } & $\mathbf{0 - 2 9}$ pts. & 0 & 0 \\
& $\mathbf{3 0 - 6 0}$ pts. & 100 & 100 \\
\hline \multirow{2}{*}{ The whole } & $\mathbf{0 - 4 9}$ pts. & 0 & 0 \\
vocabulary test & $\mathbf{5 0 - 8 4}$ pts. & $\mathbf{5}$ & $\mathbf{5}$ \\
& $\mathbf{8 5 - 1 0 0}$ pts. & $\mathbf{9 5}$ & $\mathbf{9 5}$ \\
\hline
\end{tabular}

As described in Table 1, the students scored a total of 6-10 points in the first question. Furthermore, they could obtain a total of 30 points on the second question. In addition, they could earn a total of 60 points on the third question. According to the results of this vocabulary test, the scores of $3^{\text {rd }}$ grade students justified that all scored $0-49$ points, only 5 learners obtained 51-84 points, and the majority of the students (95 learners) had 85-100 points.

\subsection{Semi-prepared Interview Form}

The consequences of the semi-prepared interview form are explained in Table 3. 
Table 3. Consequences of semi-prepared interview form

\begin{tabular}{|c|c|c|c|c|}
\hline & $\begin{array}{c}\text { Questions of semi-prepared } \\
\text { interview form }\end{array}$ & Answers of semi-prepared interview form & $\mathbf{N}$ & $\mathbf{\%}$ \\
\hline \multirow{2}{*}{1} & $\begin{array}{c}\text { Explain in detail your knowledge of } \\
\text { this application }\end{array}$ & I learned new French vocabulary words about family members. & 10 & 50 \\
I formed correct sentences in French. & 10 & 50 \\
\hline 2 & $\begin{array}{c}\text { What are the positive results of this } \\
\text { study? }\end{array}$ & $\begin{array}{c}\text { This study develops our lexical knowledge of French vocabulary. } \\
\text { This study improves our linguistics knowledge of French. }\end{array}$ & $\begin{array}{c}12 \\
15\end{array}$ & 60 \\
\hline 3 & $\begin{array}{c}\text { What are the negative consequences } \\
\text { of this research? }\end{array}$ & This research had no negative aspects. & 20 & 100 \\
\hline
\end{tabular}

As seen in Table 2, on the first question, half of the students responded that they learned new words about family members in French vocabulary. Furthermore, half of the learners indicated that they had structured nearly correct phrases in French. In addition, in response to the second question, 12 learners approved that this research allows them to develop their vocabulary knowledge in French. On the other hand, 15 students indicated that this study permitted them to obtain new correct linguistic knowledge in French. Finally, they believed that this application had no negative effects.

\section{Conclusions}

In consequence, this research is composed of two parts: quantitative and qualitative data as in the other mixed studies. The results of the vocabulary test, formed by the vocabulary test (quantitative method), verified that nearly all students (95 learners) earned good scores (85-100 points). The scores, structured by the semi-prepared interview form (qualitative method), justified that everybody had good opinions about this application.

\subsection{Discussions}

This study consisted of a vocabulary test (quantitative test) and a semi-prepared interview (qualitative method) form. According to the results of this vocabulary test, nearly everybody scored high points (85-100 points). The responses during the interview indicated that the university students learned new words and constructed correct sentences in French. Also, the learners approved that this research had no negative effects.

Similarly, firstly, [55] and [51] justified that the students learned easily and effectively the words and synonyms in foreign languages through phonetic association and through Data Driven Learning (DDL). In addition, [52], [48] and [49] justified that the learners gained autonomy and spoke efficiently in EFL and also in FFL classes. Finally, [38], [49], [41], [20] and [64] verified that the students improved their knowledge and obtained academic success in both EFL and FFL classes through web-based applications.

\subsection{Recommendations}

The recommendations for future research are enumerated below:

(i) This research should explore students in various countries of the world;

(ii) This study should be applied during the primary and secondary educational stages;

(iii) Such research should be conducted in EFL, in FFL, and in other foreign language classes; and

(iv) It should be applied at A2, B1, B2, and C1 language levels.

\section{REFERENCES}

[1] Dozin, F. (2014) Langues en contact - langues en contraste. Typologie, plurilinguismes et apprentissages, International Journal of Bilingual Education and Bilingualism, 17 (5), 624-627, doi: 10.1080/13670050.2013.809912.

[2] 10 bonnes raisons d'apprendre le français (10 good reasons to learn French). Retrieved July, 14, 2017 from http://www.diplomatie.gouv.fr/fr/politique-etrangere-de-la-fra nce/francophonie-et-langue-francaise/les-actions-pour-la-pro motion-du-francais-dans-le-monde/article/10-bonnes-raisonsd-apprendre-le.

[3] Trim, J. L. M. (2011). Using the CEFR: Principles of good practice. University of Cambridge ESOL Examinations, Retrieved July, 16, 2017 from

http://www.cambridgeenglish.org/images/126011-using-cefrprinciples-of-good-practice.pdf.

[4] Council of Europe (2001). Common European Framework of Reference for Languages: Learning, teaching, assessment. USA: Cambridge: Cambridge University Press.

[5] Fan, M. (2003). Frequency of use, perceived usefulness, and actual usefulness of second language vocabulary strategies: A study of Hong Kong learners. The Modern Language Journal, 87 (2), 222-241.

[6] Willerman, B., \& Melvin, B. (1979). Reservations about the keyword mnemonic. Canadian Modern Language Review, 35,443-453.

[7] Graves, M. F. (1987). The roles of instruction in fostering vocabulary development, In M. G. McKeown \& M. E. Curtis (Editors.). The nature of vocabulary acquisition (165-184). USA: Hillsdale, NJ: Erlbaum.

[8] Nation, I. S. P. (1990). Teaching and learning vocabulary. Boston, Mass: Heinle \& Heinle.

[9] Oxford, R. (1990). Language learning strategies: What every teacher should know. USA: Boston: Newbury House. 
[10] Crookall, D., \& Oxford, R. (1990). Vocabulary learning: A critical analysis of techniques. TESL Canada Journal, 7 (2), 9-30.

[11] Schmitt N. \& Schmitt, D. (1995). Vocabulary notebooks: theoretical underpinnings and practical suggestions. ELT Journal, 49, 133-243

[12] Hogben, D., \& Lawson, M. J. (1996). The vocabulary learning strategies of foreign language students, Language Learning Journal, 46 (1), 101-135.

[13] Benson, P. (2001). Teaching and researching: Autonomy in language learning. UK: London: Longman.

[14] Nation, I. S. P. (2001). Learning vocabulary in another language. USA: Cambridge: Cambridge University Press.

[15] Tekin, M. (2004). A comparative study on effects of presenting vocabulary in different sets on the students' productive vocabulary knowledge. Unpublished Master Thesis, Turkey: Çanakkale: Çanakkale On Sekiz Mart University Education Sciences Institute.

[16] Karatay, H. (2007). Kelime öğretimi (Teaching vocabulary). Gazi University Journal of Gazi Education Faculty (GUJGEF), 27 (1), 141-153.

[17] Siriwan, M. (2007). English vocabulary learning strategies employed by Rajabhat University students. Unpublished Doctoral Dissertation, Thailand: Suranaree University of Technology.

[18] Riankamol, N. (2008). A survey study of vocabulary strategies of gifted English students at Triam Udomsuksa school in the first semester of academic year 2008. Unpublished Master Thesis, Bangkok: Thamasat University.

[19] Arıkan, A. \& Taraf, H. U. (2010). Contextualizing young learners' English lessons with cartoons: Focus on grammar and vocabulary. Procedia Social and Behavioral Sciences, 2 $5212-52125$

[20] Aslım Yetiş, V. (2010). L'utilisation d'Internet pour l'enseignement du vocabulaire: Une étude pour le FLE. Hacettepe University Journal of Education, 39, 44-56.

[21] He, Y. (2010). A study of L2 vocabulary learning strategies. Unpublished Master Dissertation, Europe: Sweden: Kristiansatd University

[22] Asgari, A., \& Mustapha, G. B. (2011). The type of vocabulary learning strategies used by ESL students in the University Putra Malaysia. Journal of English Language Teaching, 4 (2), 84-90.

[23] Hassanzadeh, M., \& Khatib, M. (2011). Vocabulary learning strategies of Iranian upper-intermediate EFL learners. Journal of International Education Studies, 4 (2), 144-152.

[24] Kalaycioğlu, H. E. (2011). The effect of picture vocabulary games and gender on four year-old children's English vocabulary performance: An experimental investigation. Unpublished Master Thesis, Ankara: ODTÜ University Social Sciences Institute.

[25] Öcal, M. (2011). The use of "Robin Hood" in the comparison of two methods in teaching foreign language vocabulary: Total Physical Response and Grammar Translation Method. Unpublished Master Thesis, Turkey: Istanbul: Fatih University Social Sciences Institute.
[26] Ajideh, P., \& Jaffari, A. (2012). Exploring vocabulary learning strategy use of Iranian EFL learners across different proficiency levels. Journal of Basic and Applied Scientific Research, 2 (11). 11803-11811.

[27] Barekat, B., \& Karimi, S. (2012). Vocabulary learning strategies: The effect of level of proficiency on the strategy use. Science Road Publishing Corporation Journal, 6(1), 79-87.

[28] Bektaş Bedir, S. (2012). Algısal öğrenme stillerinin yabancı dilde kelime ögrenmeye ve hatırlamaya etkisi (The effects of presenting vocabulary in different sets on the students' productive vocabulary knowledge). Unpublished Master Thesis, Turkey: Tokat: Gaziosmanpaşa University Education Sciences Institute.

[29] Chou, M. (2012). Assessing English vocabulary and enhancing young English as a Foreign Language (EFL) learners' motivation through games, songs and stories. Education, May 2012, 42 (3), 1-14.

[30] Coşkun, O. (2012). La place de la compétence écrite dans les nouvelles approches de l'enseignement du français langue étrangère: Le cadre européen commun de référence pour les langues et la réalisation de la perspective actionnelle (The place of written competency in new approaches to teaching French Foreign Language: The Common European Framework of Reference for Languages and application of the Action-Oriented Approach). Unpublished Doctoral Disseration, Turkey: Ankara: Gazi University Education Sciences Institute.

[31] Gülten, D. (2012). Evaluating the efficiency of NLP applications for the teaching of English vocabulary of young learners: Adapting songs. Unpublished Master Thesis, Turkey: Ankara: Başkent University Education Sciences Institute.

[32] Khezerlou, S., \& Sadeghi, K. (2012). Self-regulated vocabulary strategy use: Implication for CALL and individual variables. MEXTESOL Journal, 36 (1), 1-17.

[33] Pourshahian, B., Rezvani Kalajahi, S. A. \& Yousefi Azarfam, A. (2012). Does applying vocabulary learning strategies vary based on gender? The case of Turkish EFL learners. Journal of Research on Humanities and Social Sciences, 2 (4), 1-10.

[34] Amirian, S. M. R., \& Heshmatifar, Z. (2013). A survey on vocabulary learning strategies: A case of Iranian EFL university students. Journal of Language Teaching and Research, 4 (3), 636-641.

[35] Büyükikiz, K. K. \& Hasırc1, S. (2013). Yabancı dil olarak Türkçenin öğretiminde sözcük öğretimi üzerine bir değerlendirme. Mustafa Kemal University Journal of Social Sciences Institute, 10 (21), 145-155.

[36] Erol, A. Y. (2013). Developing the reading skill objectıves in accordance with Common European Framework. Unpublished Master Thesis, Turkey: Mersin: Çă̆ University Social Sciences Institute.

[37] Lin-Fang, W. (2013). A study of factors affecting college students' use of ESL vocabulary learning strategies. International Journal of Humanities and Social Sciences, 3 (19), 202-208.

[38] Ganea, A. (2014). L'exploitation des ressources authentiques virtuelles dans l'enseignement du français langue étrangère (The use of virtual authentic documents in French teaching). Synergies Roumanie, 9, 43-51. 
[39] Juffs, A. \& Friedline, B. E. (2014). Sociocultural influences on the use of a web-based tool for learning English vocabulary. System, Number: 42, 48-59.

[40] Sunaergin Çakır, Ș. Z. (2013). Fransızca öğretiminde Avrupa Ortak Başvuru Metni uygulamalarının dinlediğini anlama becerisine etkisi (The effects of CEFR applications on listening skills in French teaching). Unpublished Doctoral Dissertation, Turkey: Ankara: Ankara University Social Sciences Institute.

[41] Robb, E., Sinatra R. \& Eschenauer, R. (2014). Vocabulary theatre: A peer-teaching approach for academic vocabulary acquisition. Journal of Education and Training Studies, 2 (1), 117-126. doi:10.11114/jets.v2i1.247.

[42] Sarığlu, M. (2014). The use of mnemonic devices for minimizing cross-association in teaching vocabulary to primary school EFL learners. Unpublished Master Thesis, Turkey: Bursa: Uludağ University Education Sciences Institute.

[43] Taheri, M. (2014). The effect of using language games on vocabulary retention of Iranian elementary EFL learners. Journal of Language Teaching and Research, 5 (3), 544- 549.

[44] Dolmac1, A. (2015). Developping spiral teachpng model for vocabulary learning: $A$ communicative and social constructivist language teaching perspective. Unpublished Master Thesis, Turkey: Ankara: Gazi University Education Sciences Institute.

[45] Lavoie, C. (2015). Trois stratégies efficaces pour enseigner le vocabulaire: Une expérience en contexte scolaire innu (Three strategies to learn vocabulary: An experimental study). Revue canadienne de linguistique appliquée, 18 (1), 1-20.

[46] Oflaz, (2015). Geleneksel ve alternatif yabancı dil öğretim yöntemlerinde Almanca kelime öğretimi (German vocabulary teaching in traditional and alternative foreign language teaching methods). Turkish Studies International Periodical For the Languages, Literature and History of Turkish or Turkic, Winter 2015, 10 (3), 695-712.

[47] Önem, E. E. (2015). A study on the effects of meditation on anxiety and foreign language vocabulary learning. Journal of Language and Literature Education, 15, 149-162.

[48] Parlak, E. \& Kartal, E. (2016). L'exploitation didactique d'un site d'apprentissage : L'exemple de TV5 Monde (The didactic exploitation of a learning site: The example of TV 5 Monde). Synergie Turquie, 8, 123-134.

[49] Solak, E. \& Avc1, B. D. (2015). Bilgisayar destekli yabancı dil eğitim yazılımı olan DYNED programının öğretmen görüşleri açısından değerlendirilmesi (Evaluation of DYNED sotfware language program from teachers' perspective). The Journal of Academic Social Science Studies International Journal of Social Science (JASS), Winter II 2015, Number: 31, 235-247. Doi:http://dx.doi.org/10.9761/JASSS2697.

[50] Şahinler, A. (2015). Kinect kullanilan 3 boyutlu (3D) sanal gerçeklik uygulamalarının ilkokul ögrencilerinin yabancı dilde kelime ögrenimine etkisi (The impact of Kinect usable $3 D$ virtual reality applications on young learners' vocabulary development in foreign languages vocabulary learning). Unpublished Master Thesis, Turkey: Istanbul: Fatih University Social Sciences Institute.
[51] Aşık, A., Sarlanoğlu Vural, A. \& Akpınar, K. D. (2016). Lexical awareness and development through data driven learning: Attitudes and beliefs of EFL learners. Journal of Education and Training Studies, March 2016, 4 (3). doi:10.11114/jets.v4i3.1223.

[52] Behbani, A. R. (2016). A survey of university students' knowledge of vocabulary learning strategies and influential factors in Middle East. Journal of Language Teaching and Research, 7 (4), 646-654, July 2016. doi: http://dx.doi.org/10.17507/jltr.0704.03.

[53] Demir, E. (2016). The effects of presenting vocabulary in different sets on the students' productive vocabulary knowledge. Unpublished Master Thesis, Turkey: Eskişehir: Anadolu University Education Sciences Institute.

[54] Işık, İ. \& Semerci, N. (2016). İlkokul 3. sınıf öğrencilerine İngilizce kelime öğretiminde eğitsel oyunların akademik başarıya etkisi (The effect of teaching english vocabulary to third graders through educational games on academic achievement). Çankırl Karatekin University Journal of Institute of Social Sciences, 7 (1): 787-804.

[55] Bozavl1, E. (2017). Effect of phonetic association on learning vocabulary in foreign language. Journal of Education and Training Studies, 5 (1), 35-41. doi:10.11114/jets.v5i1.1968.

[56] Sharifi, A. Ghanizadeh, A. \& Jahedizadeh, S. (2017). The effect of simulation on middle school students' perceptions of classroom activities and their foreign language achievement: A mixed-methods approach. International Electronic Journal of Elementary Education (IEEJE), March, 2017, 9 (3), 667-680.

[57] Yavuz, A. (2017). Some suggested practices to develop speaking skills and communicative competence of B1 level EFL learners at tertiary level. Unpublished Doctoral Dissertation, Turkey: Ankara: Hacettepe University Education Sciences Institute.

[58] Lowes, R. \& Target, F. (1998). Helping students to learn: A guide to learner autonomy. UK: London: Richmond Publishing.

[59] Gleitman, L. \& Landau, B. (1996). The acquisition of the lexicon. Amsterdam: MIT/Elsevier Publishing.

[60] Catalan, J. M. R. (2003). Sex differences in L2 vocabulary learning strategies. International Journal of Applied Linguistics, 13 (1), 54-77.

[61] Gil, J. P. (2014). L'enseignement-apprentissage $d u$ vocabulaire en classe de FLE. Proposition d'activités. Unpublished Master Thesis, Spain: Palencia, Valladolid University.

[62] Creswell, J. W. (2009). Research design: Qualitative, quantitative, and mixed methods approaches. Thousand Oaks, USA: CA: Sage Publishing, Inc.

[63] Apprendre le français avec Lexique FLE (Learning French with Lexique FFL). Retrieved May, 4, 2017 from http://www.lexiquefle.free.fr.

[64] Baturay, M. H., Yıldırım, İ. S. \& Daloğlu, A. (2007). Web-tabanlı İngilizce kelime öğretimi ve tekrar modeli (A web-based English language vocabulary teaching and repetition model). Journal of Polytechnic, 10 (3), 241-245. 